\title{
PROGRAM BIMBINGAN BELAJAR DI PUCANG ARJO, SURABAYA SEBAGAI UPAYA PENINGKATAN KUALITAS PENDIDIKAN UNTUK SISWA TK HINGGA SD (SEKOLAH DASAR)
TUITION PROGRAM IN PUCANG ARJO, SURABAYA AS A MEANS OF ENHANCING EDUCATION QUALITY FOR KINDERGARTEN AND ELEMENTARY SCHOOL STUDENTS
}

\section{Anggara Tirta Kusuma ${ }^{1}$, Rommy Sigit Fernanda ${ }^{2}$, Rohmatus Zazilah ${ }^{3}$, Ivangga Dwiputra Leksono ${ }^{4}$, Shindy Septia Dewi ${ }^{5}$, Rachmad Pujo Sakti ${ }^{6}$, Avita Fitri Agustin $^{7}$}

1,2,3,4,5,6 Fakultas Ekonomi dan Bisnis Universitas Airlangga, ${ }^{7}$ Fakultas Kesehatan Masyarakat, Universitas Airlangga

Email : anggara.tirta.kusuma-2018@feb.unair.ac.id

\begin{abstract}
Widespread of Covid-19 throughout the world in a fast rate pushes WHO to declare its status as a global pandemic. In February 2021, the virus have been already infecting 233 nations in the world. The effect of Covid-19 is present in all aspect of society, and one of them is education sector. The most prominent effect of Covid-19 on education is the erasure of traditional learning method through physical class, and the encouraged uses of online learning. Nevertheless, with the usage of e-learning contain several disadvantages, and one of them is the ineffectiveness of student to understand the courses and skills necessary in the education. In fact, according to several sources, student who come from lower social-economi classes in society tend to fail at grasping and understanding lesson from the teachers in the online-learning context,compared to the higher-upper clasess student. From those problems, we tried to provide a solution in the form of tutoring program which will be held at Pucang Arjo, Kelurahan Kertajaya, Kecamatan gubeng, which the majority of the people who live in here come from the lower social-economic status and profession, for instance, market merchant, driver of online transportation, and all other low-income job that makes their children ignored in terms of education aspect. The purpose of this community service is to help the students in terms of knowledge, skills, and understanding towards their courses in their respective grades. Methods used in this community service is by the means of tutoring them while also maintaining healthy protocols to prevent covid-19 spread. The result of this community service, are, the tutoring programs are succesfully held within 1 weeks and being responded by the students positively. This is indicated by the enthusiasm from the participants. Also, the knowledge, understanding, and skills from the students rises significantly after the program was held. With this tutoring programs, the students which mainly composed from kindergarten and elementary grade, gain more knowledge and skills after participating in this program.
\end{abstract}

Keywords : Education in the pandemic era, tutoring programs

\begin{abstract}
abstrak
Covid-19 menyebar dengan sangat masif serta cepat dalam waktu yang relatif singkat yang membuat WHO memberinya status sebagai pandemi berskala global. Pada bulan Februari 202, virus ini mampu menginfeksi 233 negara di dunia. Pengaruh dari Covid-19 yang juga berdampak di segala sektor kehidupan, termasuk sektor pendidikan. Dampak dari Covid-19 ini adalah, diberlakukannya model pembelajaran daring antara peserta didik dengan pengajar. Tetapi dengan model pembelajaran daring, pemahaman dari peserta didik terhadap pelajaran yang disampaikan oleh guru ini menjadi kurang efektif dipahami. Ditambah dengan data bahwa siswa yang berasal dari keluarga dengan status sosial-ekonomi menengah ke bawah merasakan dampak yang paling besar jika dibandingkan dengan keluarga dengan status menengah-ke atas. Atas dasar permasalahan tersebut, maka kami mencoba menawarkan solusi berupa program
\end{abstract}


bimbingan belajar yang dilaksanakan di Pucang Arjo, Kelurahan Kertajaya, Kecamatan Gubeng, yang secara susunan kependudukan masyarakatnya banyak yang berprofesi sebagai pedagang pasar, supir ojek online, dan beberapa pekerjaan dengan penghasilan menengah-kebawah lainnya yang membuat anak-anak mereka juga kurang tersentuh secara pendidikan. Tujuan dari pengabdian masyarakat ini adalah untuk membantu siswa secara pemahaman dan kemampuan dalam proses pendidikan mereka. Adapun metode yang digunakan adalah dengan melakukan bimbingan belajar secara langsung bersama siswa dengan tetap melaksanakan protokol kesehatan. Hasil dari kegiatan pengabdian masyarakat ini adalah terlaksananya program bimbingan belajar selama 1 minggu, dan mendapatkan respon positif dari peserta program. Hal ini diindikasikan dengan antusiasme dari peserta didik ketika mengikuti program bimbingan belajar. Selain itu, kemampuan dan pengetahuan mereka juga meningkat pasca mendapatkan program bimbingan belajar tersebut. Dengan program bimbingan belajar ini, peserta didik menjadi lebih meningkat wawasan dan kemampuan mereka pada tingkat prasekolah dan sekolah dasar.

Kata Kunci : Bimbingan belajar, Pendidikan di Masa Pandemi.

\section{PENDAHULUAN}

COVID-19 (Corona Virus Disease) adalah penyakit yang disebabkan oleh SARS-CoV2. Virus ini berasal dari Kota Wuhan, Provinsi Hubei, China pada tanggal 31 Desember 2019. Sampai saat ini, berdasarkan data terbaru, per bulan Februari tahun 2021, virus ini sudah masuk ke 233 negara dengan jumlah terkonfirmasi sebanyak 104.790 .123 orang dan korban meninggal sebanyak 2.285.048. World Health Organization (WHO) telah menetapkan kondisi ini sebagai masalah kesehatan global. Pada tanggal 2 Maret 2020, Virus ini terdeteksi masuk ke Indonesia setelah terdapat dua WNI yang positif mengidap COVID-19. Hingga saat ini, pada tanggal 6 Februari 2021, telah terdapat 1.147.010 kasus positif, 939.184 dinyatakan sembuh dan 31.393 dinyatakan meninggal dunia (Kemenkes 2021).

Wabah COVID-19 ini tidak hanya memengaruhi sektor kesehatan saja, tetapi juga sektor-sektor selainnya seperti ekonomi, pendidikan, pariwisata, dan berbagai sektor yang selainnya (Uddin et al. 2020). Karena pertimbangan beberapa dampak negatif dari penerapan stay at home, yang kemudian disusul dengan pemberlakuan kebijakan study at home dan work from home, maka pemerintah melakukan revisi pedoman pencegahan COVID-19 di Indonesia. Perubahan ini dinamakan new normal yang selanjutnya dirubah dengan nama Adaptasi Kebiasaan Baru (AKB). Pada penerapan AKB, disampaikan bahwa seluruh sektor sudah mulai berangsur aktif kembali, tetapi tetap menerapkan protokol kesehatan yang sudah disampaikan.

Akibat dari Pandemi Corona virus disease 2019 ini juga sudah dirasakan pada dunia pendidikan. Berdasarkan data dari UNESCO, lebih dari 160 negara telah menerapkan penutupan kegiatan akademik, yang berdampak kepada proses pendidikan yang dijalani oleh peserta pendidikan di seluruh dunia. Data dari UNESCO juga menunjukkan bahwa sebanyak 220.520.510 peserta didik terkena dampak oleh covid-19,. Sejauh ini, India dan China memiliki jumlah peserta didik terbesar yang terdampak karena pandemi covid-19 ini, dan di Indonesia sebanyak 68,265,787 terkena dampak dari Covid-19.

Akibat dari wabah yang menimpa seluruh dunia ini, sebanyak 577.305.660 peserta didik dari jenjang TK hingga SMA terkena risiko dari covid-19 dari sisi pendidikan. Selain itu, sebanyak mahasiswa yang terkena potensi resiko dari covid-19 dari sisi pendidikan ini mencapai 86.034.287 orang (Nugroho, 2020). Di Indonesia saat ini, banyak sekolah 
dasar, sekolah menengah pertama dan sekolah menengah atas juga sudah menerapkan metode pembelajaran jarak jauh. Tetapi, konsekuensi dari model pembelajaran daring tersebut adalah, banyak peserta didik yang terkena dampak negatif dari pembelajaran jarak jauh ini. Berdasarkan data dari blogs.worldbank.org, ditemukan bahwa siswa yang berasal dari keluarga sosio-ekonomi yang menengah ke bawah mengalami penurunan kinerja dari sisi akademik karena penutupan sekolah akibat covid-19.

Berdasarkan data dari beberapa jurnal, model pembelajaran daring juga memiliki beberapa tantangan dan hambatan yang dapat menjadi permasalahan bagi peserta didik. Menurut Petrides' (2002), beberapa peserta didik yang mencoba menggunakan sistem pembelajaran daring, merasakan kurangnya tingkat responsifitas dalam pembelajaran dengan konteks online jika dibandingkan dengan pembelajaran offline pada umumnya. Hal yang serupa juga ditemukan pada studi yang dilakukan oleh Hara dan Kling (1999) dimana para peserta didik merasakan kurangnya respons dari pengajar, jika dibandingkan dengan konteks pembelajaran tatap muka.

Selain tantangan berupa persepsi dari peserta didik yang menganggap bahwa responsifitas dari penyelenggara pendidikan ini kurang, juga terdapat tantangan lainnya yaitu kurangnya rasa kebersamaan, atau meningkatnya rasa kesendirian yang dialami oleh peserta didik. Vonderwell (2003) melaporkan bahwa partisipan online learning mengindikasikan kurangnya hubungan yang terjalin dengan pengajar, jika dibandingkan dengan pembelajaran tatap muka. Salah satu partisipan menyampaikan "saya masih merasa belum mengenal sama sekali kepribadian dan informasi lainnya yang berkaitan dengan guru saya". Woods (2002) menyampaikan bahwa para peserta didik yang melaksanakan pendidikan secara daring ini merasa terisolasi dari peserta didik yang lain dan merasa tidak bisa maksimal berinteraksi seperti pada pembelajaran luring.

Anak-anak yang memiliki orang tua yang tingkat pendidikannya rendah, serta memiliki kesibukan untuk bekerja karena kondisi ekonomi menengah ke bawah, dalam konteks pembelajaran daring di masa pandemi ini, memiliki kecenderungan untuk membiarkan anak-anaknya bermain dibandingkan dengan belajar. Orang tua mereka cenderung kurang menyadari nilai penting dari pendidikan bagi anak mereka. Akibatnya, orang tua mereka cenderung kurang partisipastif dalam hal pendidikan yang sebenarnya penting bagi anak-anak mereka. (Gupta dan Khairina : 2020).

Hal ini juga tidak dipungkiri juga terjadi di Pucang arjo, Kelurahan Kerta Jaya, Kecamatan Gubeng. Dimana salah satu permasalahan yang dihadapi oleh penduduk pucang arjo, khususnya anak-anak usia dini dan anak-anak yang menempuh pendidikan dasar adalah kurang efektifnya pendidikan dengan menggunakan metode daring. Kurang efektifnya pendidikan tersebut tampak ketika beberapa siswa tingkat sekolah dasar, dan pra sekolah yang masih belum menguasai ilmu dan kemampuan yang seharusnya mereka dapat kuasai berdasarkan pada buku dan materi yang disampaikan. Menurut pengakuan dari beberapa orang tua peserta didik, hal ini disebabkan karena keterbatasan sekolah daring, yang membuat mereka akhirnya tidak dapat menguasai wawasan dan kemampuan tersebut dengan optimal.

Hal ini diperparah dengan latar belakang orang tua peserta didik yang mayoritas berasal dari kondisi sosio-ekonomi menengah ke bawah. Dengan beberapa orang tua yang berprofesi sebagai pedagang pasar, supir ojek online, dan berbagai profesi selainnya yang menuntut mereka untuk mencari nafkah, kerap membuat mereka tidak sampai 
berpartisipasi secara aktif dalam pendidikan anak mereka. Hal ini sebelumnya, ketika pembelajaran masih dilakukan secara tatap muka, tidak menjadi masalah karena mereka dapat mempercayakan nasib anak mereka kepada pihak pendidik, yaitu sekolah dalam hal pendidikan. Tetapi karena konteks yang berbeda, maka sekarang ini pihak pendidik yaitu guru, tidak dapat berkontribusi secara maksimal. Orang tua lah yang saat ini berperan maksimal dalam membantu pendidikan anak mereka. Tetapi karena kondisi perekonomian tersebut, membuat orang tua peserta didik tidak dapat berkontribusi secara maksimal dalam pendidikan anak mereka.

Permasalahan di atas merupakan permasalahan yang serius yang memiliki urgensi untuk diselesaikan melalui program pengabdian masyarakat. Berkaitan dengan hal tersebut, maka kegiatan pengabdian berupa program bimbingan belajar yang ada di daerah Pucang Arjo bertujuan untuk membantu proses belajar siswa pra sekolah dan sekolah dasar yang terhambat dalam pemahaman terhadap materi karena keterbatasan fasilitas sekolah daring. Nantinya diharapkan, seluruh siswa yang mengikuti kegiatan ini dapat terbantu untuk meningkatkan kemampuan akademis mereka, baik tingkat pra sekolah maupun tingkat sekolah dasar.

\section{METODE PENGABDIAN MASYARAKAT}

Kegiatan pengabdian masyarakat ini dilakukan dengan melalui beberapa tahapan yang terdiri dari tahap persiapan, tahap pelaksanaan, dan tahap monitoring evaluasi. Tahap persiapan yang pertama adalah pertemuan dengan BPB Linmas Kota Surabaya untuk mengurus surat perijinan terkait KKN di Pucang Arjo, Kelurahan Kertajaya, Kecamatan Gubeng dengan berbekal surat pengantar dari Universitas Airlangga. Setelah mendapat surat perijinan dari pihak BPB Linmas Kota Surabaya, kelompok kami melakukan prasurvei yang dilakukan di lokasi sasaran yakni Pucang Arjo, Kelurahan Kertajaya, Kecamatan Gubeng. Kelompok kami melakukan kunjungan ke lokasi sasaran bertemu dengan perangkat desa antara lain Ketua RT 05 RW 05 dan masyarakat sekitar. Pertemuan dilakukan untuk menyampaikan program kegiatan KKN yang akan dilaksanakan disana yakni salah satunya ialah program bimbingan belajar untuk anakanak dengan kriteria yang sedang menempuh pendidikan TK serta SD kelas 1 hingga 4. Dalam pertemuan ini kelompok kami di Pucang Arjo mengumpulkan informasi mengenai daftar anak yang sesuai kriteria. Informasi ini menjadi bahan untuk melakukan pemetaan dan menyusun jadwal mengajar yang efektif dan efisien.
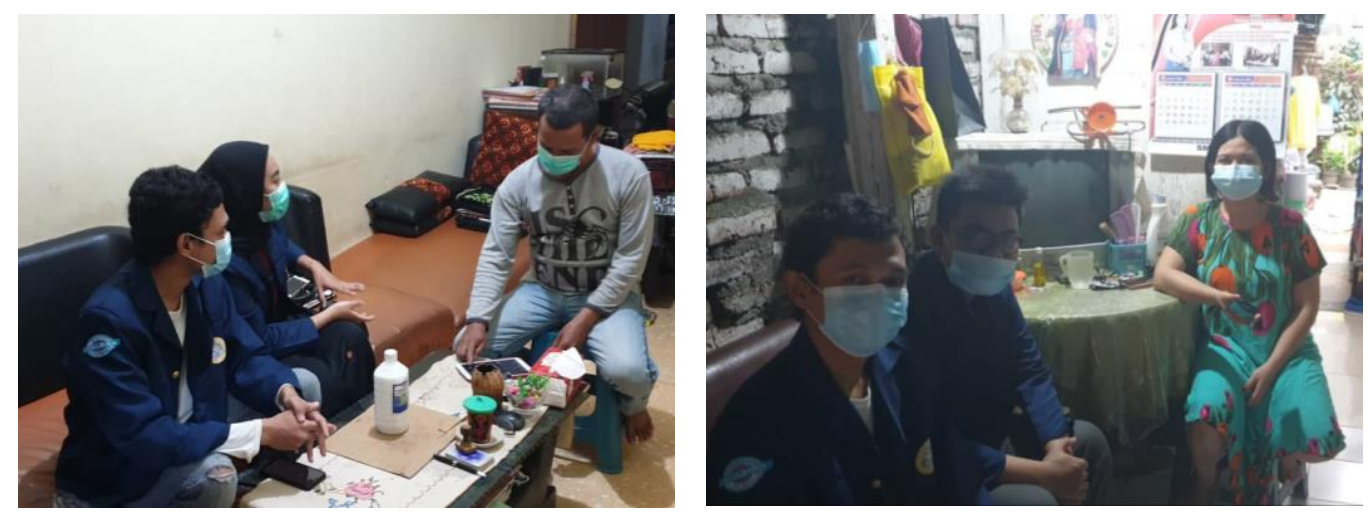

Gambar 1 Koordinasi dengan Ketua RT dan Warga 
Setelah tahap persiapan telah matang, berlanjut ke tahap 2 yaitu pelaksanaan kegiatan. Kegiatan bimbingan belajar dilaksanakan di Balai RW 05 Pucang Arjo yang berlangsung selama 1 minggu, dimulai dari jam 18.00 hingga 20.00. Teknis kegiatan bimbingan belajar sebagai berikut : (1) Kelompok kami menuju Balai RW 05 Pucang Arjo sebelum jam 18.00. (2) Melakukan persiapan disana seperti penataan meja belajar, pembersihan ruangan, penyiapan dokumentasi, serta menyediakan alat-alat sesuai protocol kesehatan seperti masker, handsanitizer, sabun cair, dan faceshield.

Tahap akhir yaitu tahap monitoring evaluasi dilakukan dengan menilai beberapa hal yakni: (1) Meningkatnya pemahaman pengetahuan dari anak-anak yang dibimbing selama 1 minggu oleh kelompok kami .(2) Efektifnya materi pelatihan berupa modul sebagai media pembelajaran. Setelah itu, laporan akhir dan laporan keuangan disusun sebagai bentuk pertanggungjawaban kegiatan.

\section{HASIL DAN PEMBAHASAN}

Berdasarkan latar belakang masalah yang dipaparkan, beberapa poin permasahalan yang dapat diambil adalah : (1) Keadaan pandemic yang mengharuskan siswa-siswi belajar dan sekolah dari rumah. (2) Kebijakan WFH yang diambil ini mengakibatkan kurangnya penanaman nilai-nilai pendidikan bagi siswa-siswi. (3) Kurangnya fokus belajar dari siswa-siswa apabila dilakukan di rumah.(4) Fasilitas pembelajaran yang kurang mendukung bagi sebagian siswa-siswi.

Berkaitan dengan hal tersebut, kelompok 137 KKN Universitas Airlangga tahun 2021 menciptakan salah satu program kerja dalam pengabdiannya ke masyarakat, yaitu program Bimbingan Belajar atau Bimbel. Bimbel ini dilakukan secara offline dengan syarat protocol kesehatan yang ketat, yaitu wajib memakai masker, diatmbah faceshield bagi pengajar, penyemprotan disinfektan sebelum dan sesudah bimbel, wajib mencuci tangan sebelum mulai bimbel, membatasi jumlah siswa-siswi yang ikut bimbel, melakukan shift jadwal pada kelompok kami sebagai pengajar, dan disiplin terhadap waktu yang telah ditentukan. Bimbel ini dilakukan di Balai RW 05 Pucang Arjo, kelurahan Kertajaya, kecamatan Gubeng dengan peserta bimbel adalah anak TK dan siswa-siswi dari kelas satu sampai dengan empat SD. Bimbingan belajar dilakukan selama dua minggu, hari senin sampau jumat, pukul 18.00-20.00.
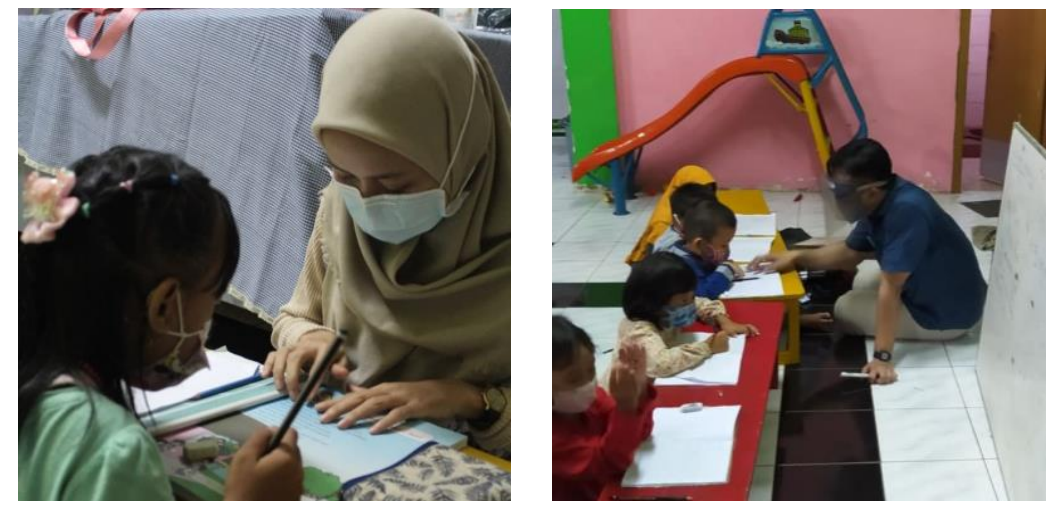

Gambar 2 Pelaksanaan Bimbingan Belajar

Metode pembelajaran yang kami berikan adalah dengan menyesuaikan materi dan topik yang diberikan oleh pihak sekolah. Jadi tiap anak harus membawa buku paket atau tema sebagai panduan pembelajaran, serta apabila ada pekerjaan rumah, maka juga akan 
dibahas bersama. Kami juga memberikan semacam quiz atau tebak-tebak an yang berhubungan dengan materi pembelajaran, dan yang berhasil menjawab akan kami berikan hadiah. Dengan metode tersebut, maka suasana pembelajaran akan cair dan seru, tidak terlalu tegang serta menghilangkan kesan bosan yang mungkin dirasakan anak-anak ketika belajar di rumah.

Hasil yang diharapkan dari bimbingan belajar tersebut adalah dapat meningkatkan pemahaman anak-anak terhadap materi pelajaran yang diberikan oleh pihak sekolah, dapat mengerti pentingnya pendidikan, serta menghilangkan rasa bosan dan jenuh pada mereka karena harus belajar di rumah dalam waktu yang lama.

Dari pengamatan terhadap peserta didik, mereka antusias dengan dilaksanakannya program bimbingan belajar karena selama ini mereka mengaku kurang memahami materi yang disampaikan oleh pengajar dalam proses pembelajaran daring. Selain itu juga, dari pengamatan kami terhadap beberapa peserta didik, secara pengetahuan dan wawasan mereka bertambah, jika dibandingkan dengan sebelum diadakannya bimbingan belajar. Hal lain yang teramati menjadi hasil dalam proses bimbingan belajar ini adalah, meningkatnya kemampuan dari para peserta didik, seperti kemampuan membaca, menulis, berhitung yang semakin cepat dan terampil dilakukan oleh para peserta program bimbingan belajar.

\section{KESIMPULAN DAN SARAN}

Program bimbingan belajar yang dilakukan di Pucang Arjo Surabaya, Kelurahan Kertajaya, Kecamatan Gubeng, adalah salah satu upaya yang kami lakukan untuk membantu mengurangi dampak negatif yang disebabkan oleh pandemi covid-19 pada sektor pendidikan. Dengan adanya pandemi covid-19 membuat para siswa menjalankan pembelajaran jarak jauh, dan akhirnya menghasilkan beberapa akibat, seperti kurangnya pengetahuan dan pemahaman yang dapat diserap oleh peserta didik ketika pembelajaran pandemi. Ditambah dengan kondisi latar belakang keluarga menengah ke bawah yang membuat orang tua mereka semakin kecil partisipasinya dalam proses pendidikan anakanak mereka. Dengan adanya program bimbingan belajar tersebut, diharapkan dapat membantu para siswa tingkat prasekolah hingga SD memperoleh kemampuan dan pengetahuan yang memadai dalam pendidikan. Dengan memberikan pembelajaran sesuai dengan materi dari buku para siswa, diharapkan dengan program bimbingan belajar ini dapat meningkatkan pemahaman para peserta bimbingan belajar kami dalam hal pelajaran. Tentu dalam pelaksanaan bimbingan belajar tersebut diaktualisasikan dengan mentaati protokol kesehatan seperti cuci tangan, mengenakan masker, faceshield dan social distancing.

Saran yang dapat kami berikan untuk program bimbingan belajar ini adalah, hendaknya program ini juga dapat dilaksanakan secara linier dengan kontrol dan kepedulian dari orang tua serta institusi pendidikan terkait terhadap pemahaman dan kemampuan para peserta didik, agar nantinya pelaksanaan bimbingan belajar ini dapat berjalan beriringan dengan partisipasi dari orang tua, guru serta institusi pendidikan agar murid-murid pra sekolah dan sekolah dasar yang kami bimbing, mendapatkan kemampuan dan pengetahuan yang maksimal untuk mencapai masa depan yang cerah walaupun dengan keterbatasan pembelajaran jarak jauh. 


\section{DAFTAR PUSTAKA}

Abidah, Azmil \& Nuurul H, Hasan \& Simamora, Roy \& Fehabutar, Daliana \& Mutakinati, Lely. (2020). "The Impact of Covid-19 to Indonesian Education and Its Relation to the Philosophy of "Merdeka Belajar". Studies in Philosophy of Science and Education. 1. 38-49. 10.46627/sipose.v1i1.9.

Genomics, Epidemiology, Vaccines and Therapeutic Interventions." Viruses 2020 12: 1-18. https://doi.org/doi:10.3390/v12050526.

Gupta, Deepali \& Khairina, Noviandri Nurlaili. (2020). Retrieved 06 February 2021 from https://blogs.worldbank.org/eastasiapacific/covid-19-and-learning-inequitiesindonesia-four-ways-bridge-gap

Hara, N., \& Kling, R. (2001). "Student distress in Web-based distance education". EDUCAUSE Quarterly, 3

Hara, N., \& Kling, R. (1999). "Students' frustrations with a web-based distance education course". First Monday, 4(12). Retrieved April 15, 2002, from http://www.firstmonday.dk/issues/issue4_12/index.html

Kementrian Kesehatan, "Satgas Penanganan Covid-19. 2021. Beranda. Retrieved February 6, 2021 from https://covid19.go.id/

Nugroho, R. S. (2020, March 14). Corona: 421 juta pelajar di 39 negara belajar di rumah, kampus di Indonesia Kuliah Online. Retrieved February 06, 2021, https://www.kompas.com/tren/read/2020/03/14/120000765/corona-421-jutapelajardi-39-negara-belajar-di-rumah-kampus-di-indonesia

Petrides, L.A. (2002). Web-based technologies for distributed (or distance) learning: Creating learning-centered educational experiences in the higher education classroom. International Journal of Instructional Media, 29(1), 69 - 77.

Uddin, Mohammed, Farah Mustafa, Tahir A Rizvi, Tom Loney, Hanan Al Suwaidi, Ahmed H Hassan Al-marzouqi, Afaf Kamal Eldin, et al. 2020. "SARSCoV2/COVID-19: Viral

UNESCO. (2021). Education emergencies. Retrieved February 06, 2021 from https://en.unesco.org/themes/education-emergencies/coronavirus-school-closures

Vonderwell, S. (2003). An examination of asynchronous communication experiences and perspectives of students in an online course: A case study. Internet and Higher Education, 6, $77-90$.

WHO. 2021. Retrieved February 06, 2021 "WHO Coronavirus Disease (COVID-19) Dashboard." 2021. https://covid19.who.int/table. 